\title{
Use of a highly dispersed chalk additive for the production of concrete for transport structures
}

\author{
Olga Borziak $^{1}$, Svitlana Chepurna ${ }^{2,}{ }^{*}$, Tatyana Zidkova $^{2}$, Anna Zhyhlo ${ }^{2}$, \\ and Andrii Ismagilov ${ }^{1}$ \\ ${ }^{1}$ Ukrainian State University of Railway Transport, Feuerbach sq. 7, 61050 Kharkiv, Ukraine \\ ${ }^{2}$ O.M. Beketov National University of Urban Economy in Kharkiv, Kulikovska descent 12, 61002 \\ Kharkiv, Ukraine
}

\begin{abstract}
The concretes used for transport infrastructure facilities are exposed to the active impact of corrosive environment; therefore, such concretes face raised demands as for water repellency, frost resistance and corrosion resistance. These properties can be improved due to the use of additives that have a different kind of effect. This research paper gives consideration to the influence of added highly-dispersed chalk on the physical and mechanical properties of concrete, in particular, water repellency and frost resistance. Experimental data show that the doping of highly-dispersed chalk results in a reduced water repellency and an increased frost-resistance of concrete. The basic physical and mechanical properties of concretes depend on the structure with a special particle packing of the matrix in the interlayers between the structure -forming elements of each level. Assumingly, the influence of added highlydispersedchalk on the water-repellency and frost-resistance of pavement concrete is conditioned by the optimal arrangement of chalk particles (matrix particles) in the interlayers between the cement particles and the filler (structure-forming elements).
\end{abstract}

\section{Introduction}

Recently, much attention has been paid to the production of new composite binders, which have improved physical and mechanical characteristics and durability indicators, which is achieved through the use of mineral additives [1-3]. The use of local mineral resources and industrial wastes [4], in particular, sedimentary gypsum rocks and chalk [5], became especially urgent. This will solve environmental issues and get low-price local raw materials for obtaining new materials. It is known [6], that the use of various types of limestone and chalk powders as fillers improves the strength properties of concrete, including road concrete as well.

Concrete used at transport constructions is exposed to active influence of aggressive environment, therefore its durability depends on filtration properties [7]. The introduction of fine-dispersed mineral powders, which are used as active mineral additives or inert fillers for binders, leads to a change in the phase composition of Portland cement hydration

* Corresponding author: s.chepurna0274@gmail.com 
products [8] and the structure of concrete, leading to the formation of a more dense structure of the composite and, consequently, will increase the durability of the structures as a whole [9-11]. The effectiveness of the mineral additive depends on the uniformity of its distribution over the volume of the composite, so it is advisable to add the admixture to the concrete mixture in the form of a suspension.

Proceeding from the foregoing, it was suggested that replacing part of the astringent additive with highly disperse chalk would improve the water resistance, frost resistance and corrosion resistance of concrete, without impairing its strength characteristics.

The aim of the paper is to study the effect of the addition of highly disperse chalk on the physical and mechanical characteristics of concrete, in particular water and frost resistance.

\section{Research methods and materials}

\subsection{Materials}

To evaluate the effect of the addition of highly disperse chalk on the water and frost resistance of concrete, a series of samples were manufactured, the consumption of components for the manufacture of which is given in the Table 1.

As a binder, Portland cement was used without additives (CEM I $42.5 \mathrm{~N}$ ). The fine aggregate used was $0 / 4$ fraction sand. The coarse aggregate used was $5 / 10$ and 10/20 fraction crushed stone. The water-cement ratio was limited by the indices of workability of the concrete mixture.

Table 1. Consumption of components for making concrete samples.

\begin{tabular}{|c|c|c|c|c|c|c|}
\hline \multirow{2}{*}{$\begin{array}{c}\text { Batch } \\
\text { number }\end{array}$} & \multicolumn{5}{|c|}{ Consumption of components, $\mathrm{kg}$ per $1 \mathrm{~m}^{3}$ concrete mixture } & \multirow[b]{2}{*}{$\mathbf{W} / \mathbf{C}$} \\
\hline & Cement & Sand 0/4 & $\begin{array}{c}\text { Crushed } \\
\text { stone 5/10 } \\
\end{array}$ & $\begin{array}{c}\text { Crushed } \\
\text { stone 10/20 }\end{array}$ & Chalk & \\
\hline 1 & 377 & 580 & 420 & 780 & 0 & 0.466 \\
\hline 2 & 340 & 580 & 420 & 780 & 37 & 0.460 \\
\hline 3 & 302 & 580 & 420 & 780 & 75 & 0.462 \\
\hline 4 & 275 & 580 & 420 & 780 & 105 & 0.468 \\
\hline 5 & 277 & 580 & 420 & 780 & 150 & 0.472 \\
\hline
\end{tabular}

The specific surface of particles of chalk is $10,000 \mathrm{~cm}^{2} / \mathrm{g}$, which excludes the influence of the strength of the rock itself. The chalk was pre-grounded in a dispersant. After dispersion, the size of the chalk particles in the suspension did not exceed 5 microns. For uniform distribution, the addition of highly dispersed chalk was introduced into a concrete slurry mixture. Formulations based on Portland cement were prepared with the replacement of $10,20,30$ and $40 \%$ of binder to highly-dispersed chalk to determine water resistance and frost resistance.

\subsection{Method for determining the water resistance of concrete}

The waterproof test was carried out in accordance with [12] by the "wet spots" method. For the test, sample cylinders, with the height and diameter of $150 \mathrm{~mm}$ were made. Samples were placed in a metal cage and exposed to unilateral action of water under pressure. The pressure was increased by steps of $0.2 \mathrm{MPa}$ for 2 minutes and retained for 16 hours. The method is based on measuring the maximum pressure at which water is not filtered through 
the sample. at the same time with the definition of water resistance, the compressive strength of concrete samples of each series was determined.

\subsection{Method for determining the frost resistance of concrete.}

The frost resistance was determined in accordance with [13]. To determine the frostresistance of the concrete mixture, sample-cubes were made, in the size $100 \times 100 \times 100 \mathrm{~mm}$. The samples were frozen at a temperature of $-18( \pm 2)^{\circ} \mathrm{C}$ for 4 hours, and then thawed at a temperature of $+20( \pm 5)^{\circ} \mathrm{C}$ for at least 2 hours. Frost resistance was determined in two ways: the first method - samples of concrete subjected to freezing and thawing in water, the second - freezing and thawing is carried out in a 5\% solution of sodium chloride $(\mathrm{NaCl})$. After a certain number of freezing and thawing cycles, the strength of the samples was determined. The frost resistance was estimated by the coefficient of frost resistance $C_{f}$ according to the formula:

$$
C_{f}=\frac{R^{f}}{R},
$$

where $R^{f}$ is the strength of the concrete samples after alternating freezing and thawing; $\mathrm{R}$ - strength of samples of concrete that have not been frozen. The concrete grade is determined by the number of cycles of freezing and thawing, after which concrete samples lose strength by no more than $15 \%$.

\section{Results of experimental studies}

The experiments showed that the water resistance index of a series of samples modified with $10 \%$ highly-dispersed chalk increased by $20 \%$, compressive strength by $8.4 \%$ compared to control samples without an additive (Fig 1).

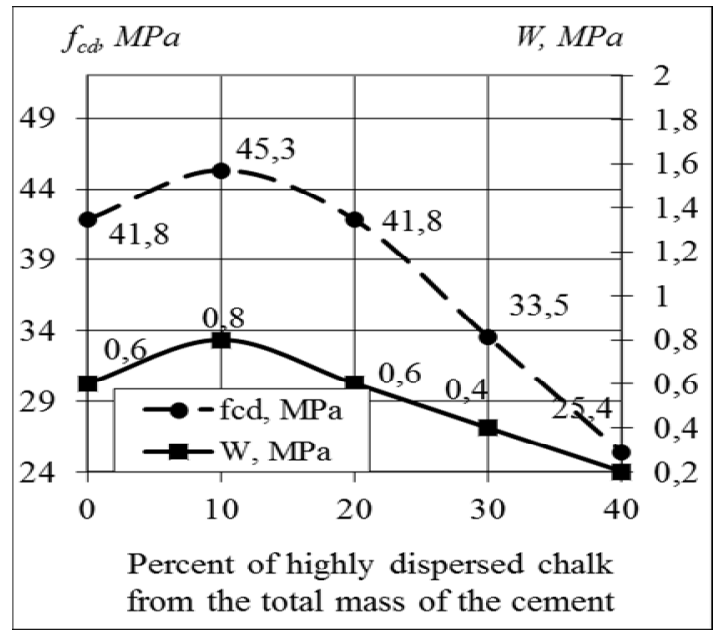

Fig. 1. Dependence of strength at contraction $\left(f_{c d}\right)$ and waterproofness $(W)$ of concrete samples according to the chalk inclusion.

Waterproofness grade of concretes modified with $20 \%$ chalk corresponds to the brand of the control sample. It should be noted that concretes modified with $30 \%$ and $40 \%$ chalk 
have high water resistance grades (W4, W2, respectively), despite the low compressive strength.

According to the results of the study of frost resistance the maximum frost resistance grade is 400 , the samples modified by 10 and $20 \%$ chalk correspond. The loss of strength in these samples after 400 cycles of freezing and thawing in the 1 st method of determining frost resistance, and 150 cycles - in the second method, was no more than $5 \%$. In this case, control samples and samples modified with 30 and $40 \%$ chalk after 400 (150) cycles were completely destroyed. The concrete grade for frost resistance of these samples was 300 .

Table 2. The value of the coefficient of frost resistance.

\begin{tabular}{|c|c|c|c|c|c|c|c|c|}
\hline \multirow{2}{*}{$\begin{array}{c}\text { Batch } \\
\text { number }\end{array}$} & \multicolumn{8}{|c|}{ Number of freezing and thawing cycles } \\
\cline { 2 - 9 } & \multicolumn{7}{|c|}{$\mathbf{1}^{\text {st }}$ method } & \multicolumn{4}{c|}{$\mathbf{2}^{\text {nd }}$ method } \\
\hline 1 & 1.16 & 1.2 & 1.18 & - & 1.21 & 1.18 & 1.0 & - \\
\hline 2 & 1.18 & 1.25 & 1.2 & 0.98 & 1.28 & 1.26 & 1.15 & 0.95 \\
\hline 3 & 1.14 & 1.18 & 1.12 & 0.95 & 1.25 & 1.21 & 1.1 & 0.8 \\
\hline 4 & 1.09 & 1.12 & 1.05 & - & 1.15 & 1.11 & 0.89 & - \\
\hline 5 & 1.02 & 0.95 & 0.75 & - & 1.11 & 1.04 & 0.82 & - \\
\hline
\end{tabular}

\section{Discussion}

It is known [14] that the basic physical and mechanical properties of concrete depend on the structure, which is represented by the nature of the packing of the matrix particles in the inter-layers between the structure-forming elements of each level (Fig 2).

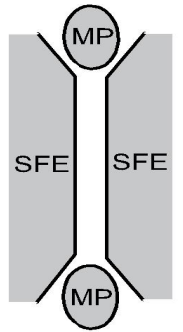

(a)

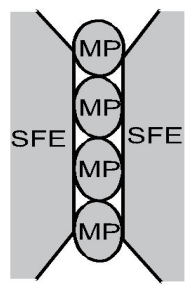

(b)

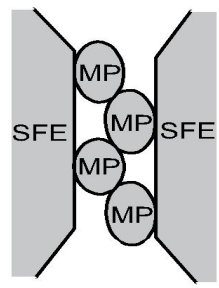

(c)

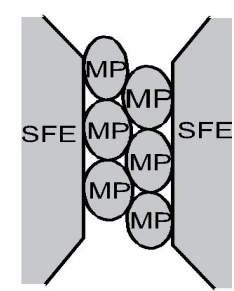

(d)

Fig. 2. Packing of particles of a matrix (MP) in a layer between the structure-forming elements (SFE): (a), (b) - the non-optimal structure of the interlayer; (c), (d) is the optimal structure of the interlayer [14].

The fine chalk used as an additive is a mixture of calcite grains (5 to 1 microns) has an angled or coiled form. The size of the particles of highly dispersed chalk can be compared with the size of the capillaries of the cement stone, so the replacement of chalk with cement parts contributes to the formation of a more dense structure. At the micro level, an optimal package of matrix particles is formed in the layers between the structure-forming elements: carbonate particles, which dissolve poorly in water, fill the layers between the particles of cement and fine aggregate, which increases the density and reduces the permeability of the concrete (Fig. 3). Since the volume of capillary pores does not usually exceed $40 \%$, therefore, the total volume of the binding agent can be increased by $40 \%$ due to the highly dispersed chalk to fill them. 
It is known that carbonate additives affect the hydration process of Portland cement [8, 15], in particular, such stable compounds are formed as calcium hydrobromoaluminates $\mathrm{CaO} \times \mathrm{Al}_{2} \mathrm{O}_{3} \times \mathrm{CaCO}_{3} \times \mathrm{nH}_{2} \mathrm{O}$.

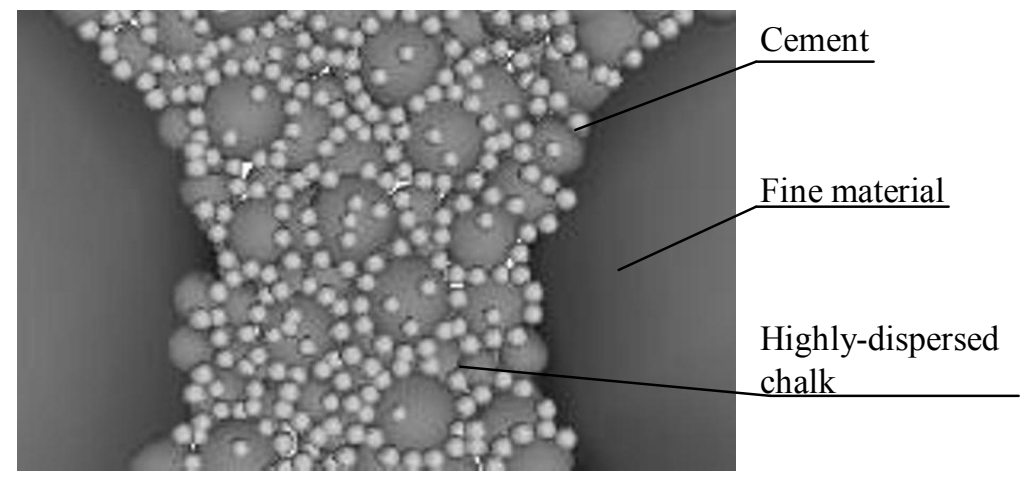

Fig. 3. Spatial-structural scheme of the placement of particles of cement and highly dispersed chalk.

According to [16], the surface of particles of organogenic carbonate rocks, in particular chalk, is covered with amorphous silica. When calcium hydroxide reacts with silica, lowbasic calcium hydrosilicates are formed. Thus, the use of highly disperse chalk leads to a decrease in the content and binding of free calcium hydroxide, as well as the aluminate phase, to stable hydration products. This contributes to the increase of the corrosion resistance of cement stone under the influence of aggressive media containing sulfate and chloride ions, as well as magnesium ions [17].

\section{Conclusions}

According to the studies, the use of a highly dispersed chalk additive reduces the capillary porosity and compacts the structure of the cement stone, which helps reduce the effective diffusion coefficient of aggressive ions, increase the water resistance and frost resistance of concrete. The change in the phase composition of the products of Portland cement hydration in the presence of a fine chalk additive and the formation of such hardy compounds as calcium hydrogencarbonate and low-basic calcium hydrosilicates also increases the corrosion resistance of cement stone and concrete. This will increase the stability of structures to the influence of aggressive media and, therefore, increase their durability. The developed compositions can be used in the production of road concrete.

\section{References}

1. U. Marushchak, M. Sanytsky, T. Mazurak, Y. Olevych, Eastern-European Journal of Enterprise Technologies, 6/6 (84), 50-57 (2016)

2. M. Sanytsky, T. Kropyvnytska, R. Kotiv, Advanced Materials Research, 923, 42-47 (2014)

3. U. Maruchchak, M. Sanytsky, S. Korolko, Y. Shabatura, N. Sydor, Eastern-European Journal of Enterprise Technologies, 2/6 (92), 34-41 (2018)

4. O. Shynkevych, Y. Lutskin, A. Aniskin, Technical Journal, 11 (4-2017), 160-165 (2017)

5. Mridul Garg, A.K. Minocha, Neeraj Jain, Construction and Building Materials, 25 (2), 944-949 (2011) 
6. Wenzhong Zhu, John C. Gibbs, Cement and Concrete Research, 35 (8), 1457 (2005)

7. Peter A. Claisse, Transport Properties of Concrete (Woodhead Publishing, 2014)

8. A.A. Plugin, R.F. Runova, International Journal of Engineering Research in Africa, 36, 69-73 (2018)

9. O.Yu. Bazhenova, ISAEECE, AER, 124 (2017)

10. E. Lutskin, E. Shinkevich, Technical Journal, 9 (1-2015), 27-33 (2015)

11. T. Kropyvnytska, R. Semeniv, H. Ivashchyshyn, MATEC Web of Conferences, 116, 01007 (2017)

12. DSTU B V.2.7-170:2008. Construction Materials. Concretes. Methods for determining average density, humidity, water absorption, porosity and water repellency (State standard of Ukraine, Kyiv, 2008)

13. DSTU B V.2.7-42-97. Building materials. Methods of determination of water absorption, density and frost resistance of building materials and products (State standard of Ukraine, Kyiv, 1997)

14. A.N. Plugin, A.A. Plugin et al. Osnovy teorii tverdeniya, prochnosti, razrusheniya $i$ dolgovechnosti portlandtsementa, betona i konstruktsiy iz nikh (Naukova dumka, Kyiv, 2012)

15. O.S. Borzyak, S.M. Chepurna, Collected scientific works of Ukrainian State University of Railway Transport, 175, 110-117 (2018)

16. I.M. Gorkova et al., Priroda prochnosti $i$ deformatsionnyie osobennosti mela $i$ nekotoryih melopodobnyih porod (Akademiya nauk, 1962)

17. S.N. Chepurna, A.A. Plugin, O.S. Borzyak, Naukovii visnyk budivnitstva, 1 (91), $292-$ 298 (2018) 